\author{
Aleksandra JADACH-SEPIOŁO \\ Dr, Szkoła Główna Handlowa w Warszawie, Katedra Miasta Innowacyjnego \\ e-mail: a.jadachsepiolo@gmail.com
}

\title{
REWITALIZACJA MIAST W POLSCE - NIEDOSKONAŁA ODPOWIEDŹ NA PROBLEM DEPOPULACJI
}

\begin{abstract}
Abstrakt: Zgodnie z Krajową Polityką Miejską 2023 kompleksowa rewitalizacja ma być najbardziej zaawansowanym procesem przemian, koncentrowanym na obszarach zdegradowanych, którego efektem będzie trwałe ożywienie społeczne i gospodarcze, poprawa jakości życia i warunków pracy oraz prowadzenia działalności gospodarczej. Duża część wójtów, burmistrzów i prezydentów miast postrzega rewitalizację jako szansę, aby dzięki tym zmianom zatrzymać (lub przynajmniej ograniczyć) proces depopulacji. Czy rewitalizacja naprawdę daje takie możliwości? Czy depopulacja jest zjawiskiem, na które można oddziaływać za pomocą działań rewitalizacyjnych i czy w związku z tym przedstawianie analiz demograficznych jako ilustracji negatywnych zjawisk jest poprawne metodologicznie? W artykule przedstawiono próbę odpowiedzi na powyższe pytania i sformułowano refleksję na temat ewolucji metodyki sporządzania diagnoz w trakcie opracowania programów rewitalizacji.
\end{abstract}

Słowa kluczowe: rewitalizacja, depopulacja, programy rewitalizacji.

\section{URBAN REGENERATION IN POLAND - AN IMPERFECT RESPONSE TO THE PROBLEM OF DEPOPULATION}

Abstract: According to the National Urban Policy 2023, complex urban regeneration in Poland is the most advanced process of transformation, concentrated in degraded areas, resulting in permanent social and economic revitalization, improvement of quality of life and conditions for work and business. A large proportion of mayors and city presidents perceive revitalization as an opportunity to stop or at least reduce a depopulation, due to these changes. Does revitalization really give us this possibility? Is depopulation a phenomenon that can be affected by revitalization activities and is therefore methodologically correct in describing demographic analyzes as negative phenomena? The author tried to answer these questions and to reflect on the evolution of diagnostic methods in the development of revitalization programs.

Keywords: urban regeneration, depopulation, urban regeneration programs.

\section{WSTĘP}

Najbardziej kompleksową odpowiedzią na zjawiska degradacji ma być zgodnie z Krajową Polityką Miejską 2023 (KPM 2015, s. 78) kompleksowa rewitalizacja - proces przemian koncentrowany na obszarach zdegradowanych, którego efektem będzie trwałe ożywienie społeczne i gospodarcze, poprawa jakości życia i warunków do pracy oraz prowadzenia działalności gospodarczej. Jednym z czynników skutkujących degradacją przestrzeni polskich gmin jest - zgodnie z przytoczonym dokumentem - depopulacja (KPM 2015, s. 77). „Wytyczne Ministerstwa Rozwoju w zakresie rewitalizacji w programach operacyjnych na lata 2014 -2020" (2015, 2016) wskazują, że do wyznaczenia obszaru rewitalizacji niezbędna jest diagnoza na podstawie wskaźników. Efektem tej diagnozy ma być określenie terenu o największej koncentracji negatywnych zjawisk $\mathrm{w}$ sferze społecznej oraz przynajmniej jednej z pozostałych sfer. Negatywne zjawiska spo- łeczne zostały zasygnalizowane w tych Wytycznych oraz w Ustawie z 9 października 2015 r. o rewitalizacji $1^{1}$ (m.in. bezrobocie, ubóstwo, niewystarczające uczestnictwo w kulturze, przestępczość). Depopulacja nie została w tym katalogu ujęta, jednak można go rozszerzyć o dodatkowe zjawiska specyficzne dla konkretnej gminy.

Intencją wielu organów opracowujących programy rewitalizacji, zwłaszcza dla miast, jest skoncentrowanie działań na obszarze śródmiejskim. Dane dotyczące zmian liczby ludności, szczególnie przyrostu naturalnego oraz starzenia się społeczeństwa, są łatwo dostępne, a spadek liczby urodzeń oraz wzrost liczby osób w wieku produkcyjnym i poprodukcyjnym na tych terenach jest wyraźnie widoczny. Dlatego pokusa, aby pokazywać w programach rewitalizacji procesy depopulacyjne okazuje się szczególnie silna. W tym kontekście pojawia się pytanie, czy depopulacja - mimo że 
wzmacnia degradację - powinna być analizowana jako negatywne zjawisko w programach rewitalizacji, skoro bezpośrednie oddziaływanie działań rewitalizacyjnych na spadek tendencji depopulacyjnych jest ( $w$ najlepszym razie) wątpliwe.

Autorka przedstawiła dyskusję tych problemów i sformułowała refleksję na temat ewolucji metodyki sporządzania diagnoz na potrzeby opracowania programów rewitalizacji. Badania przeprowadzono w oparciu o bazę 656 programów rewitalizacji aktualnych w latach 2007-20132, analizując treść wszystkich dokumentów pod kątem ich odniesień do niekorzystnych trendów demograficznych.

W drugiej części artykułu zostało zaprezentowane podejście do analizy niekorzystnych trendów demograficznych $\mathrm{w}$ poprzednim okresie programowania (2007-2013), zaś w trzeciej ukazano zmiany w obecnym okresie (2014-2020). Czwarta część artykułu jest natomiast studium przypadku Węgrowa ilustrującym niecodzienną w programach rewitalizacji sytuację, gdy rewitalizacja może być odpowiedzią na depopulację obszaru.

\section{NIEKORZYSTNE TRENDY DEMOGRAFICZNE JAKO KRYTERIUM WYZNACZENIA OBSZARU - PERSPEKTYWA FINANSOWA 2007-2013}

W poprzedniej perspektywie finansowej kryteria dotyczące wyznaczania obszarów zdegradowanych pochodzily $\mathrm{z}$ dokumentu unijnego $-\mathrm{z}$ art. 47 ust. 1 rozporządzenia (WE) nr 1828/2006. Poniżej wymieniono sześć spośród dziesięciu kryteriów, które odnosiły się bezpośrednio do sfery społecznej:

a) wysoki poziom ubóstwa i wykluczenia;

b) wysoka stopa długotrwałego bezrobocia;

c) niekorzystne trendy demograficzne;

d) niski poziom wykształcenia, wyraźny deficyt kwalifikacji i wysoki wskaźnik przerywania skolaryzacji;

e) wysoki poziom przestępczości i wykroczeń;

h) wysoka liczba imigrantów, grup etnicznych i mniejszościowych lub uchodźców.

Należy podkreślić, że były to kryteria wspólne dla wszystkich krajów członkowskich UE i wynikały z doświadczeń Inicjatyw URBAN i URBAN II, w których Polska nie brała udziału. Był to wspólny mianownik dla tych krajów, chociaż istotny wpływ na wybór kryterium demograficznego miały doświadczenia niemieckie - konieczność reakcji na wyludnianie się miast, szczególnie w dawnej NRD (Glock, Häußermann 2004, Strauss, Warner, Kübler 2011).

Ponieważ kraje członkowskie UE miały wybór tego, które ze wskaźników zastosują, „Wytyczne Ministerstwa Rozwoju Regionalnego w zakresie programowania działań dotyczących mieszkalnictwa” (2008), ograniczyły tę listę do pięciu wskaźników, z których trzy odnosiły się do sfery społecznej:

a) wysoki poziom ubóstwa i wykluczenia,

b) wysoka stopa długotrwałego bezrobocia,

c) wysoki poziom przestępczości i wykroczeń.

Instytucje zarządzające regionalnymi programami operacyjnymi (IZ RPO), z których współfinansowane były projekty rewitalizacyjne, formułowały zaś własne wymagania dotyczące stosowanych wskaźników, posługując się jako podstawą zapisami rozporządzenia w stosunku do wyznaczania obszarów zdegradowanych w ogóle oraz Wytycznych... (2008), do wyznaczania obszarów, na których wspierane mogły być działania z zakresu mieszkalnictwa.

Najczęściej w wyznaczaniu obu typów obszarów były stosowane dwa wskaźniki:

- liczba osób korzystających z zasiłków pomocy społecznej na 1 tys. ludności;

- liczba długotrwale bezrobotnych na 1 tys. mieszkańców.

Dla tych wskaźników (znajdujących się w Wytycznych... 2008) zostały podane wartości referencyjne dla każdego z województw oraz dla całej Polski. Wskaźniki wymienione w art. 47 ust. 1 rozporządzenia (WE) $\mathrm{nr}$ 1828/2006, a nieujęte w Wytycznych... (2008) zostały pominięte przez większość IZ RPO $\mathrm{w}$ regionalnych wytycznych. Jedynie w czterech województwach (kujawsko-pomorskim, wielkopolskim, lubelskim i warmińsko-mazurskim) IZ RPO dopuściły jako kryterium wyznaczania obszarów zdegradowanych wskaźniki demograficzne:

- dynamika (spadku) liczby ludności w wyniku odpływu i zgonów na 1 tys. mieszkańców obszaru;

- liczba ludności w wieku poprodukcyjnym na 1 tys. mieszkańców obszaru;

- saldo migracji na 1 tys. mieszkańców obszaru.

Mimo braku wymogu analizowania niekorzystnych trendów demograficznych, organy opracowujące przedstawiały $\mathrm{w}$ programach rewitalizacji dość często informacje wskazujące na występowanie tendencji depopulacyjnych (średnio 62\% miast w regionie) - tab. 1 . 
Tab. 1. Zakres informacji dotyczących niekorzystnych trendów demograficznych w programach rewitalizacji według województw (2007-2013)

\begin{tabular}{|c|c|c|c|c|}
\hline \multirow[b]{2}{*}{ Województwo } & \multirow{2}{*}{$\begin{array}{l}\text { Liczba programów } \\
\text { rewitalizacji poddanych } \\
\text { analizie (według stanu bazy } \\
\text { na } 31 \text { czerwca } 2014 \text { r.) }\end{array}$} & \multirow{2}{*}{$\begin{array}{c}\text { Informacje } \\
\text { wskazujące na } \\
\text { występowanie } \\
\text { depopulacji }\end{array}$} & \multicolumn{2}{|r|}{ Zidentyfikowane problemy } \\
\hline & & & migracje & $\begin{array}{l}\text { niekorzystne zmiany struktury } \\
\text { demograficznej (starzenie się ludności; } \\
\text { niski przyrost naturalny itp.) }\end{array}$ \\
\hline Dolnośląskie & 75 & 34 & 32 & 31 \\
\hline Kujawsko-pomorskie & 34 & 19 & 21 & 18 \\
\hline Lubelskie & 33 & 17 & 17 & 18 \\
\hline Lubuskie & 24 & 10 & 8 & 11 \\
\hline Łódzkie & 25 & 18 & 18 & 15 \\
\hline Małopolskie & 50 & 29 & 28 & 29 \\
\hline Mazowieckie & 61 & 32 & 28 & 32 \\
\hline Opolskie & 22 & 14 & 8 & 14 \\
\hline Podkarpackie & 27 & 19 & 17 & 18 \\
\hline Podlaskie & 9 & 9 & 7 & 9 \\
\hline Pomorskie & 15 & 15 & 15 & 15 \\
\hline Śląskie & 47 & 24 & 22 & 23 \\
\hline Świętokrzyskie & 28 & 28 & 26 & 28 \\
\hline Warmińsko-mazurskie & 39 & 19 & 18 & 19 \\
\hline Wielkopolskie & 61 & 22 & 21 & 22 \\
\hline Zachodniopomorskie & 38 & 18 & 16 & 18 \\
\hline Razem & 588 & 327 & 302 & 320 \\
\hline
\end{tabular}

Źródło: opracowanie własne.

Najczęściej były to ogólne informacje, czyli stwierdzenie problemu. Dane liczbowe ilustrowały zwykle zmiany struktury społecznej (starzenie się społeczeństwa, niski przyrost naturalny); rzadziej podawano dane dotyczące migracji, ale i tak stosunkowo często wskazywano je jako istotny problem obszaru przeznaczonego do rewitalizacji. Poniżej przytoczono przykładowe informacje z programów rewitalizacji:

- „Niepokojąca jest sytuacja, iż notowana jest większa liczba wymeldowań na wieś (74\%) niż w województwie małopolskim (51\%). Poza odpływem mieszkańców na tereny wiejskie, obserwowane jest zjawisko migracji do innych ośrodków miejskich oraz za granicę".

- „Zjawiskiem negatywnym jest ujemne saldo migracji, świadczące o odpływie ludności. Generalnie wynika to $\mathrm{z}$ braku miejsc pracy."

- „Kolejnym negatywnym trendem, który od kilku lat stale utrzymuje się na obszarze kryzysowym jest negatywny wskaźnik migracji. W roku 2004 negatywny wynik kształtował się na poziomie - 19, w roku 2005 był on niższy, jed- nak nadal ujemny i wynosił -8. W roku 2006 z obszaru kryzysowego wyjechało o 23 osoby więcej niż przybyło".

- „Miasto posiada niestety ujemne saldo migracji, przyczyn tego można upatrywać w stagnacji, jaką przeżywa rynek pracy na terenie miasta" (wybrane programy rewitalizacji z województwa lubuskiego, łódzkiego i małopolskiego).

Ujemne saldo migracji było podawane często jako zbiorcza wartość dla obszaru kryzysowego. Dane te, zwłaszcza dla małych miast, nie wskazują na dużą intensywność zjawiska, np. jako istotny problem podawano ujemne saldo na poziomie kilkunastu osób z obszaru zamieszkanego przez kilka tysięcy osób. Jako przyczynę wymeldowań wskazywano najczęściej nieatrakcyjną ofertę rynku pracy lub jej brak oraz dążenie do zamieszkania poza miastem. Jeśli przyczyny te zostały zidentyfikowane właściwie, można stwierdzić, że działania rewitalizacyjne nie mogły wpłynąć na ograniczenie tendencji depopulacyjnych, były one bowiem niezależne od cech danego obszaru rewitalizacji. 


\section{ZMIANA PODEJŚCIA DO ANALIZY NIEKORZYSTNYCH TRENDÓW DEMOGRAFICZNYCH}

Nowe wytyczne w zakresie rewitalizacji w programach operacyjnych na lata 2014-2020 $(2015,2016)$ wskazują, że wstępem do wyznaczenia obszaru, gdzie mają być podjęte działania rewitalizacyjne, musi być pełna diagnoza, która obejmie „kwestie społeczne oraz gospodarcze lub przestrzenno-funkcjonalne lub techniczne lub środowiskowe". Efektem diagnozy będzie określenie obszaru o największej koncentracji negatywnych zjawisk w sferze społecznej i przynajmniej jednej z pozostałych. Negatywne zjawiska społeczne (wymienione w Wytycznych... 2015, 2016) nie tworzą zamkniętego katalogu, lecz kilka z nich powinno zostać bezwględnie poddane analizie:

- bezrobocie,

- ubóstwo,

- przestępczość,

- niski poziom edukacji lub kapitału społecznego,

- niewystarczający poziom uczestnictwa w życiu publicznym i kulturalnym.

Analogiczne wymagania sformułowano w odniesieniu do gminnych programów rewitalizacji, w art. 9 ust. 1 ustawy z 9 października 2015 r. o rewitalizacji. Niezależnie od typu programu rewitalizacji organ opracowujący zdecyduje, czy w tym dokumencie znajdą się analizy obejmujące wszystkie, czy tylko wybrane z powyższych zjawisk oraz za pomocą jakich wskaźników zostaną one zilustrowane. Można rozszerzyć ten katalog np. o zjawiska specyficzne dla konkretnej gminy.

Analiza programów rewitalizacji uchwalonych przez gminy w Polsce do połowy 2016 r. wykazała, że $\mathrm{w}$ diagnozie kryzysu sfery społecznej oraz delimitacji obszarów zdegradowanych i obszarów rewitalizacji stosowano cztery wskaźniki dotyczące niekorzystnych trendów demograficznych:

- odsetek osób w wieku poprodukcyjnym w ogólnej liczbie mieszkańców,

- osoby w wieku powyżej 65. roku życia,

- przyrost naturalny na 1 tys. ludności,

- spadek liczby ludności w wyniku odpływu i zgonów na 1 tys. mieszkańców (Jadach-Sepioło, Krystek-Kucewicz 2016).

Migracje zaś najczęściej pomijano ze względu na dostępność danych w zróżnicowaniu wewnątrzmiejskim.
Zmiana podejścia w porównaniu z opisanym w drugiej części artykułu polega przede wszystkim na tym, że charakterystyka problemów demograficznych nie służy do wytyczenia (czy, jak poprzednio, do potwierdzenia) obszaru rewitalizacji, lecz do wyjaśnienia przyczyn problemów występujących na danym terenie. Rzadko wskaźniki demograficzne przytaczane są więc $\mathrm{w}$ diagnozach delimitacyjnych, częściej zaś stanowią uzupełnienie pogłębionej analizy obszaru rewitalizacji. Jest to też uzasadnione mniejszym wysiłkiem organizacyjnym przy dostępie do danych (np. dotyczących migracji) dla mniejszego terenu.

\section{STUDIUM PRZYPADKU - UJEMNE SALDO MIGRACJI JAKO SPECYFICZNA CECHA OBSZARU REWITALIZACJI}

Do rzadkości w analizowanych programach rewitalizacji należą dokumenty, w których zidentyfikowano depopulację jako specyficzny problem obszaru rewitalizacji. Najczęściej dotyczy ona całej miejscowości, a nawet powiatu lub województwa. $\mathrm{W}$ takich sytuacjach dane dotyczące nasilenia migracji nie przyczyniają się do lepszego poznania przyczyn negatywnych zjawisk na terenie rewitalizacji, a oddziaływanie planowanych w programie działań na ubytek ludności z obszaru będzie znikome.

Obserwujemy jednak przykłady miejscowości, gdzie ubytek ludności jest ściśle związany z charakterystyką obszaru rewitalizacji. Wtedy stwierdzone przyczyny ucieczki są wartościowym wkładem diagnostycznym i pozwalają odpowiednio modelować cele programu.

Jako przykład wybrano program rewitalizacji Węgrowa, miasta leżącego o $70 \mathrm{~km}$ na wschód od Warszawy. Z Węgrowa wciąż wyjeżdża na stałe część najbardziej aktywnych mieszkańców, zarówno z centrum, jak i z innych terenów tego miasta. W pierwszym przypadku opuszczają obszar rewitalizacji ludzie młodzi, przenosząc się do innej części Węgrowa, w drugim - w drugim wyjeżdżają z miasta. Oba te odpływy osłabiają potencjał rozwojowy Węgrowa jako całości, ale wpływają szczególnie negatywnie na obszar rewitalizacji.

W Węgrowie rocznie osiedla się najczęściej nieco ponad 100 osób, z czego około 3/4 pochodzi ze wsi. W latach 2008-2012 tych przyjazdów było stosunkowo mniej, od 2013 r. ich liczba ponownie rośnie. Liczba wymeldowań waha się zaś od 130 do 150 osób rocznie. 
Saldo tej migracji jest ujemne, wynosząc ostatnio od kilkunastu do 50 osób rocznie. Łącznie w latach 20052014 w Węgrowie osiedliło się 1101 osób, a wymeldowały się 1454 . Wśród przyjeżdżających tu na pobyt stały przeważają osoby $\mathrm{z}$ terenów wiejskich. Wyjeżdżają z miasta zwykle ludzie młodzi. W dłuższym okresie wpływa to na strukturę społeczną i potencjał rozwojowy miasta.

Średnie roczne saldo migracji w okresie 10 lat wyniosło w Węgrowie $-2,8 \%$, podczas gdy wskaźnik ten dla Polski wyniósł $-0,4 \%$, a dla województwa mazowieckiego $-2,6 \%$ o. Węgrów należy do miast charakteryzujących się silną tendencją wyjazdową w poszukiwaniu pracy w większym ośrodku. Stanowi to poważny problem, który nie wynika jednak ze specyfiki badanego miasta, lecz jest typowy dla regionu. $\mathrm{Z}$ rozmów przeprowadzonych na potrzeby opracowania programu rewitalizacji z przedstawicielami instytucji miejskich $\mathrm{i}$ interesariuszy podczas gromadzenia danych wynika, że odpływ (szczególnie osób młodych) jest zjawiskiem zauważalnym i niepokoi mieszkańców. Węgrów pozostaje niewielkim miastem, gdzie oferta edukacyjna kończy się na szkole ponadgimnazjalnej. Młodzi ludzie wyjeżdżają stąd na studia do Warszawy, bo w stolicy możliwości nauki, pracy i rozrywki są nieporównanie większe; tylko nieliczni po zakończeniu nauki wracają do miasta rodzinnego.

$\mathrm{Na}$ depopulację centrum wpływa splot zjawisk - w największym stopniu migracje międzygminne oraz ujemny przyrost naturalny. Zdiagnozowanym problemem Węgrowa jest malejąca liczba mieszkańców w jego centralnej części, ograniczonej obwodnicą (od północy ul. Piaskowa, od wschodu i południa ul. Traugutta i Słowackiego). Obserwowany jest stały odpływ ludności, głównie osób młodych, z obszaru rewitalizacji na peryferia miasta. Młode małżeństwa usamodzielniając się przenoszą się na tereny $\mathrm{w}$ północnej i wschodniej części Węgrowa. Pierwszą przyczyną tego zjawiska są atrakcyjne ceny tamtejszych działek ${ }^{3}$, które skłaniają do budowy domu. Odległość nie jest barierą, ponieważ obrzeża Węgrowa oddalone są od centrum nie więcej niż o kilka kilometrów, a posiadanie samochodu jest powszechne. Drugą przyczyną jest wyższa atrakcyjność tych obszarów w porównaniu z centrum, które (wg opinii mieszkańców) nie oferuje młodym atrakcji ani ciekawych form życia miejskiego.

Odpływ młodych ludzi z obszaru rewitalizacji powoduje, że potencjał rozwoju przesuwa się $\mathrm{z}$ centrum na peryferia. Przerwane zostają tradycyjne więzi międzypokoleniowe na obszarze rewitalizacji, a jego spo- łeczność starzeje się. Problem wyjazdu tej części ludności jest w tym przypadku specyficzną cechą obszaru rewitalizacji i został uwzględniony w projektach rewitalizacyjnych w Węgrowie. Przykładami nowych przedsięwzięć są specjalistyczna placówka wsparcia dziennego Remont i modernizacja budynku przy ulicy Mickiewicza 12 - dostosowanie budynku do prowadzenia działalności społecznej i medycznej, zagospodarowanie terenu zielonego wokół budynku; Klub Młodzieżowy MDM - Miejsce Dla Młodych; Utworzenie Domu Dziennego Pobytu „Senior-Wigor”, Kompleksowa modernizacja bazy edukacyjnej I LO im. Adama Mickiewicza w Węgrowie wraz z jej rozbudową, renowacją i zagospodarowaniem terenu wokół niej, w celu dostosowania jej do prowadzenia funkcji społecznych, zwłaszcza edukacyjnych i kulturalnych. Dzięki zwiększeniu atrakcyjności oferty kulturalnej i edukacyjnej centrum oraz działaniom modernizacyjnym w przestrzeni publicznej obszar ten może zacząć przyciągać młodych ludzi. Kluczowa jest też budowa mieszkań komunalnych i tworzenie oferty cenowo dostępnych mieszkań w centrum, wobec których nabycie działki i budowa domu jednorodzinnego na peryferiach nie będą pożądaną alternatywą.

\section{WNIOSKI KOŃCOWE}

Podsumowując powyższe rozważania można stwierdzić, że zmiana podejścia do opracowania diagnoz na potrzeby rewitalizacji służy uelastycznieniu ujęcia problemów obszaru rewitalizacji. Niekorzystne trendy demograficzne, które podlegały $\mathrm{w}$ poprzedniej perspektywie obowiązkowemu badaniu w kilku polskich regionach, obecnie nie są obligatoryjnym kryterium w wyznaczaniu obszarów rewitalizacji. Jest to korzystne, ponieważ depopulacja i tak dotyka większość miast w Polsce (Śleszyński 2016), a obszary rewitalizacji nie są najczęściej w sposób szczególny dotknięte jej skutkami. Jeśli nawet wyludnianie się tych terenów następuje szybciej niż w innych częściach miasta, wynika to najczęściej z charakterystyki danego ośrodka (atrakcyjność rynku pracy, bliskość dużego miasta itp.) W takiej sytuacji szczegółowa charakterystyka trendów demograficznych na obszarze rewitalizacji jest zbędnym balastem. W niektórych przypadkach jednak staje się niezbędna.

Jeśli wyludnianie obszaru rewitalizacji następuje szybciej niż w innych częściach gminy, a z analizy przyczyn depopulacji obszaru rewitalizacji wynika, że 
jest to ściśle związane ze złymi warunkami mieszkaniowymi i nieatrakcyjną ofertą mieszkaniową obszaru rewitalizacji, brakiem oferty edukacyjnej i spędzania wolnego czasu, to w celach, kierunkach działań i projektach należy uwzględnić działania na rzecz rozwiązania tych problemów. Obowiązkowym elementem pogłębionej analizy obszaru rewitalizacji jest wtedy charakterystyka zjawiska depopulacji, a system monitorowania efektów programu rewitalizacji powinien uwzględniać zmianę liczby mieszkańców obszaru jako jeden z podstawowych wskaźników obrazujących skuteczność programu.

\section{PRZYPISY}

${ }^{1}$ Dz. U. z 2015 r. poz. 1777.

${ }^{2}$ Są to wszystkie programy rewitalizacji w Polsce w badanym okresie.

${ }^{3}$ Ceny ofertowe najczęściej wynoszą od 40 do 50 zł za m², przy rozpiętości 25-100 zł za m².

\section{BIBLIOGRAFIA}

Glock B., Häußermann H., 2004, New trends in urban development and public policy in eastern Germany: dealing with the vacant housing problem at the local level, „International Journal of Urban \& Regional Research", 28, 4, s. 919-929.

Jadach-Sepioło A., Krystek-Kucewicz B., 2016, Dobór wskaźników zjawisk kryzysowych - stan zaawansowania procesu delimitacji obszarów rewitalizacji w polskich miastach, „Problemy rozwoju miast", IV, s. 31-40.

Krajowa Polityka Miejska 2023, 2015, Ministerstwo Infrastruktury i Rozwoju, Warszawa. Dostępne na: https://www.mr.gov. pl/media/10252/Krajowa_Polityka_Miejska_20-10-2015.pdf; 24.08.2017.

Strauss Ch., Warner B., Kübler A., 2011, Land-use management under depopulation tendencies in the Halle-Leipzig region: Challenges for regional and local instruments, "Journal of Town \& City Management", 2, 1, s. 32-43.

Śleszyński P., 2016, Współczesne i prognozowane uwarunkowania demograficzno-migracyjne w rozwoju miejskiego systemu osadniczego Polski, „Konwersatorium Wiedzy o Mieście”, 1(29), s. 97-106.

Ustawa z dnia 9 października 2015 r. o rewitalizacji (Dz. U. z 2015 r. poz. 1777 ). Dostępna na: http://isap.sejm.gov.pl; 24.08.2017.

Wytyczne Ministerstwa Rozwoju Regionalnego w zakresie programowania działań dotyczących mieszkalnictwa, 2008, Ministerstwo Rozwoju Regionalnego, Warszawa. Dostępne na: https:// www.funduszeeuropejskie.2007-2013.gov.pl/Dokumenty/wyty cznepolskie/who/Documents/wytyczne/wytyczne\%20-\%20mie szkalnictwo\%20-\%20aktualizacja.pdf; 24.08.2017.

Wytyczne Ministerstwa Rozwoju w zakresie rewitalizacji w programach operacyjnych na lata 2014-2020, 2015, 2016, Ministerstwo Infrastruktury i Rozwoju, Warszawa. Dostępne na: https:/www.funduszeeuropejskie.gov.pl/media/6107/Wytyczne_ dot_rewitalizacji_zatwierdzone_3VII2015.pdf oraz https://www. funduszeeuropejskie.gov.pl/strony/o-funduszach/dokumenty/wy tyczne-w-zakresie-rewitalizacji-w-programach-operacyjnych-na -lata-2014-2020/; 24.08.2017.

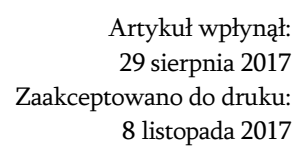

Artykuł wpłyną: owano do druku: 8 listopada 2017 